\title{
Enriching Orphans' Potentials through Interpersonal and Intrapersonal Intelligence Enrichment Activities
}

\author{
Nurulwahida Hj Azid \\ $\mathrm{PhD}$. School of Educational \& Modern Languages, University Utara, Malaysia \\ nurulwahida@uum.edu.my
}

\author{
Aizan Yaacob \\ $\mathrm{PhD}$. School of Educational \& Modern Languages, University Utara, Malaysia
}

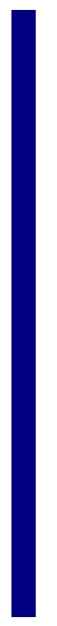

\begin{abstract}
Orphans are considered a minority and they should be given a greater emphasis so that they do not feel left out and can build their own lives without a sense of humility. This does not mean that the orphans should be pampered instead they should be given the confidence and motivation to strive for success in later life. Humility among orphans can be associated with interpersonal and intrapersonal intelligences. This study aims to evaluate the impact of problem-solving activity treatment based on the interpersonal and intrapersonal intelligences. 46 students from two orphanages were involved as the treatment group. The research design used was a one-group pretest-posttest design applied through a combination of quantitative and qualitative approaches. Enrichment activities that provided interpersonal and intrapersonal skills as evidenced in this study should be carried out regularly at orphanages. Our study has proven that orphans' rights to learn cannot be neglected and 'no child left behind 'policy needs to be carried through by everybody involved with orphans' well-being. Teachers and carers need to be trained to use these enrichment activities at their orphanages to help maximize the orphans' potentials.
\end{abstract}

Keywords: orphans, interpersonal intelligence, intrapersonal intelligence, experimental and mixed method research, enrichment activities

\section{INTRODUCTION}

Recently studies on orphans have received much attention due to the increasing number of orphans or vulnerable children throughout Africa, Europe and Asia. The rise in the number of orphans is mainly due to the death of parents from HIV and AIDS in many parts of Africa or due to war in Romania to name a few. UNICEF (2009) estimated that 12 million children under the age of 18 had been orphaned by the disease or roughly 1 in 20 children in sub-Saharan Africa. By 2015, the World Health Organization (WHO) estimates that a total of 1,629,547 people in Africa will die of AIDS. In addition, UNICEF estimates anywhere between 500 million and 1.5 billion children endure violence each year (Long, 2014). It is argued that as the number of orphans or vulnerable children increases, their communities become less capable of addressing their 
basic needs, including their needs for education (UNICEF, 2009). This is quite alarming, thus, continuous efforts will have to be fostered to ensure sustainability of orphans' development. Orphans have been defined by UNICEF and historians as "the child, who has lost one parent, often termed a 'half' or 'single' orphan'. Nixon (2014) on the other hand, postulates that the category of orphan can thus encompass numerous types of parentless children ranging from children who have lost both parents to children who have living parents but live separate from them, such as the foundling (typically an abandoned child found and cared for by non-kin or an institution) the ward (typically an orphan cared for by a legal guardian), the pauper apprentice (typically an orphaned or abandoned child consigned to labour and cared for by an apprentice master), and the street child (typically a child who has left his or her family to live and work on the street) (Nixon, 2014). In the context of the present study, orphans are categorized as children who have lost either parents or one parent and live in an orphanage cared for by a legal guardian. In Malaysia, organizations which looked after the orphans are registered under the Social Welfare Department. In these organizations, they are protected and provided with, food, shelter, education, and everyday needs including clothing and school equipment.

Many studies on orpahans have examined the technical aspects such as their basic needs including food and nutrition, health support, educational support and vocational training, psychosocial support, shelter and care. For example OVC-CARE Boston University Project (Makame, Ani \& Grantham-McGregor, 2002; Sengendo \& Nambi, 2011), yet very few looked at their psychological and social problems. Makame, Ani and Grantham-McGregor (2002) found that orphans had internalizing problems compared with non-orphans and $34 \%$ of them had contemplated suicide some time in their lives. Surprisingly, the results are higher among the females. They argued that, "orphans not only had unmet basic needs, but also had markedly increased internalizing problems, thus their long term mental health would be in jeopardy". Similarly, Sengendo and Nambi (2011) claimed that orphans suffer from negative effects as a result of parents' death, thus becoming "vulnerable and predisposed to physical and psychological risks".

Other studies have also looked at the effect of institutions or orphanages on children's development (Grady, 2009; Pappas, 2012). Grady's (2009) study was conducted in 5 countries in Asia and Africa; Cambodia, Ethiopia, India Kenya and involved 1357 orphans aged 6-12 who were in institutions and 1480 who lived in homes in the community. The purpose of the study was to examine the effects of institutions on children's wellbeing. The findings revealed that the children living in orphanages generally fared as well as those in the community or even better. In support to that, Pappas (2012) claimed that "institutionalization in early childhood can alter a child's brain and behaviour in the long run. Fortunately early intervention can stave off the effects". Thus, it is felt that there is an urgent need to expand and improve the current intervention programmes not only to meet the basic needs but also to include psychosocial support, counselling services for the orphans, and training for their careers. (Makame, Ani \& Grantham-McGregor, 2002). 
Earlier studies also indicated that adopting parents, carers and teachers lack of information on the psychological effects experienced by the orphans and failed to diagnose the problems and offer solutions to the problem. Most adopting parents lack information on the problem, and are therefore unable to offer emotional support, and school teachers do not know how to identify psychological and social problems and consequently fail to offer individual and group attention (Sengendo \& Nambi, 2011). They further elaborated that, "teachers should be retrained in diagnosing psycho-social problems and given skills to deal with them (Sengendo \& Nambi, 2011). In response to this research, the present study attempts to examine the effect of problem solving intervention on the children's Interpersonal and Intrapersonal Intelligences based on the Learner-Centred Psychological Principles. These principles were developed by the American Psychological Association. Task Force (APA, 1992) focuses on five major factors: (1) Metacognitive and cognitive, (2) Affective, (3) Developmental, (4) Social, and (5) Individual Differences. This study is in line with the fifth principle which concentrated on individual differences that stipulates that learners (regardless of ethnicity, race, gender, orphans, presence or absence of physical handicaps, religion or socioeconomic status) have unique abilities and talents, and acquired different preferences for how they learn, as well as different preferences in how they respond to learning situations and grounded in Gardner's theory of the learner-centred principle which posits that the development of a child and the way that child interprets his or her life experiences are influenced by his or her education.

\section{Conceptualizing Intelligences}

Every individual has a unique intelligence for themselves (Armstrong, 2003). Gardner (1983) defines intelligence as a set of skills that allows a person to solve a problem or produce a product or service that provides value to the culture. Campbell, Campbell, \& Dickinson (2004) added that multiple intelligences become a tool in learning while Chan (2005) explains that intelligence refers to the ability of individuals to benefit from new experiences. Howard Gardner (1983), a psychologist, founded a related theory of multiple intelligences (MI) which provides a broader view of the concept. MI introduced by Gardner is more dynamic and contains many interrelated dimensions. His work has been expanded by McKenzie (2009) who describes in detail the connection of the eight types of human intelligences which consist of verbal linguistic, logical mathematical, visual spatial, kinaesthetic, interpersonal, intrapersonal and naturalist. However, this study only focuses on the interpersonal and intrapersonal intelligences which are considered vital in shaping emotions, identity, and self-confidence of an individual. Furthermore, earlier studies have indicated that these two elements are the most crucial ones and needed most attention in the context of orphans.

\section{Interpersonal Intelligence}

Interpersonal intelligence is closely linked with emotions. Individuals who possess interpersonal intelligence will have the ability to understand the feelings of others, are highly motivated, and can interact well with others through effective communication. Generally interpersonal intelligence can mould or shape an individual to work well in groups and is able to lead, be sensitive to the feelings of others, and can recognize and 
categorize the behaviour of others (McKenzie, 2009). Research has shown that a person with interpersonal intelligence is more confident when expressing ideas and opinions, self-reliant and smart in presenting ideas and opinions. Interpersonal intelligence helps individuals to socialize with others. In a self-report measure of multiple intelligences and human behaviour of 187 participants, Furnham (2009) reported that 'Intrapersonal intelligence' is closely linked with Stability and Conscientiousness; 'Interpersonal intelligence' with Extraversion; 'Linguistic intelligence' with Openness; 'Mathematical intelligence' with Agreeableness and Conscientiousness (Furnham, 2009).

\section{Intrapersonal Intelligence}

Intrapersonal intelligence is also known as "self-smart" (Armstrong, 2000) whereby individuals who possess intrapersonal intelligence have the ability to understand their own feelings, emotions and needs. They are also able to understand their inner feelings, and are capable of doing self-reflection. They have the ability to concentrate and make reasoning, know themselves well in many aspects of feelings, intentions, goals in life, and self-motivation, but sometimes they like to be alone (Dummett, 2006). According Kornhaber, Fierros and Veenema (2004), the application of interpersonal and intrapersonal intelligence in life can foster efficiency to master the important thinking discipline. Through individual intrapersonal intelligence an individual can identify him/herself by understanding the purposes, goals and will of his or her life. On the other hand, through intrapersonal intelligence one can identify oneself by understanding one's own needs, aspirations and requirements.

In relation to intervention programme, there are plenty of activities proposed to improve interpersonal and intrapersonal intelligence of children. Some examples of activities that can stimulate interpersonal intelligence are group activities, charities and interviewing specific figures. Even activities that require individuals to tell their own feelings, desires, ambitions, and write stories are also able to encourage individuals to use interpersonal intelligence. The intrapersonal intelligence activities are related to individual activities and self-report on matters of interest or hobby. Activities that encourage them to plan for the future, to talk about their ambition and desire in the future, the importance of a particular individual in their lives are examples of activities that can stimulate students to use their intrapersonal intelligence.

\section{Problem Statement}

Student development is closely related to human resource development (Zimbardo, 2001) and priority should be given to teenagers because they are the national asset and the pillar for the development of human capital (Ministry of Education, 2001). Students usually know themselves at the age between 13 and 18 years (Wan Abdul Kader, 2000) and this is the crucial time to develop their personality and to shape their emotions and self-esteem. According to a study conducted by Van Ijzendoorn, Luijk and Juffer (2008) the development of teenagers are affected by homelessness particularly among those who live in orphanages. In Malaysia, orphans are normally being associated with low socio-economic status, low self-esteem and neglected (Melissa, 2008).

Amirah (2009) discovered that orphans still have a sense of shame and low self-esteem when they are in a crowd. Similarly, previous studies conducted by Jamaluddin, Azizi, 
Noordin and Siti Zainab (2011) found that orphans have high levels of depression, had difficulty to decide, considered themselves as failures, felt persecuted, and were extremely sad. In addition, Ikhsan Othman \& Rohizani Yaakub (2010) make connections between issues of bully, mugging and robbery and interpersonal intelligence, while drugs and suicide with intrapersonal intelligence. Realizing the fact that low self-esteem and high level of depression faced by orphans are associated with interpersonal and intrapersonal intelligences, it is felt that this study needs to be explored further as they play an important role in improving human social development, particularly among adolescents (Wicks \& Israel, 2003). Besides, intelligence of an individual is different and not all individuals are able to do the same thing in a similar manner (Gardner, 2004).

\section{METHOD}

\section{Research questions}

This study attempts to answer the following questions:

1) What are the interpersonal and intrapersonal intelligence profiles of the orphans in the pre and the post- tests?

2) Did the interpersonal treatment activities affect the orphans' interpersonal profiles?

3) Did the intrapersonal treatment activities affect the orphans' intrapersonal profiles?

4) What are the orphans' perceptions of the interpersonal and intrapersonal intelligence treatment activities?

\section{Research hypothesis}

a) There is no significant treatment effect on the orphans' interpersonal intelligence profile.

b) There are no significant treatment effects on the orphans' intrapersonal intelligence profile.

\section{Research methodology}

We adopted "One-Group pre-test-post-test design" whereby a group of orphans went through a pre-test, received treatment and were later given a post test (Campbell \& Stanley, 1999). The treatment group was measured based on a number of outcome variables. This research design can be described as follows:

\begin{tabular}{|c|c|c|}
\hline \multicolumn{3}{|c|}{ Treatment Group } \\
\hline $\mathrm{O} 1$ & $\mathrm{X}$ & $\mathrm{O} 2$ \\
\hline $\begin{array}{l}\text { Pre-test Interpersonal } \quad \& \\
\text { Intrapersonal Intelligences }\end{array}$ & $\begin{array}{l}\text { Treatment: Problem Solving } \\
\text { Activity Based Interpersonal } \\
\text { and Intrapersonal Intelligence }\end{array}$ & $\begin{array}{l}\text { Posttest Interpersonal \& } \\
\text { Intrapersonal Intelligences }\end{array}$ \\
\hline
\end{tabular}

Figure 1: One-Group Pre-Test Post-Test Design (Campbell \& Stanley, 1999) 
Both quantitative and qualitative methods were employed in this study because they provide a holistic view of the events that took place without any manipulation from the researcher (Creswell, 2011). We believe that the data obtained from both methods can be used to support the findings from multiple data sources and to provide a holistic view of the effectiveness of the treatment. As such, an interview was used to support the findings of the pre-test and the post-test.

\section{The Participants}

Non probability sampling or a type of purposive sampling on 46 participants from two orphanages in the Northern area of Malaysia was used. Ten (10) of them were interviewed to gain understanding of the views concerning the treatment activities. The participants ( $n=10$ male and $n=36$ females) involved were in the junior high school aged between 13-15 years old. The imbalanced breakdown between male and female participants is because one of orphanages (MTO) has only female participants.

\section{Instrument}

\section{Reliability}

The instrument which was adopted from McKenzie (2000) was translated into Bahasa Malaysia. Cronbach's alpha reliability for original version of McKenzie (2000); Multiple Intelligence inventory is 0.62 for interpersonal intelligence and 0.75 for intrapersonal intelligence (Karim Hajhashemi \& Wong Bee Eng, 2010). The translated version of the instrument has been used in previous studies (Nurulwahida \& Ahmad Azman, 2014; Zaidatun, 2002) and it has achieved high reliability of .72 for interpersonal and .655 for intrapersonal. For this study Cronbach alpha for interpersonal intelligence is .65 and .70 for intrapersonal intelligence.

\section{Internal Validity}

In addition, the instruments which have been translated into the Malay language (mother tongue) have undergone face and content validity. A total of six experts appointed consist of language, psychology experts and educationists. The six experts have confirmed that the instruments translated into the Malay language have excellent face and content validity.

Researchers also maintain internal validity by maintaining the period of time between the pre and the post-test. According to Campbell and Stanley (1966), in experimental research, the good time period for post-test is one month, six months, or one year after pre-test. Immediate post-test evaluation will not produce a convincing impression. Therefore, for this study the post-test was administered two months after the pre-test as to produce more convincing results. Meanwhile, at least one week between treatment and post-test is sufficient to obtain a convincing impression (Best \& Kahn, 1998; Campbell \& Stanley, 1966).

The interpersonal and intrapersonal activities were conducted for a month and the measurement of interpersonal and intrapersonal intelligences was done before (pre) and after (post-test) the activities were undertaken (Chua, 2009). There were 10 items each for both instruments and the participants were asked to tick " $\sqrt{ }$ " the item which was the most relevant to them. The total score for both instruments were $100 \%$ and the scoring 
was based on the number of items agreed by the participants. The high score indicates that the participants have high level of intelligence and vice-versa.

The levels of intelligences, on the other hand, were categorized based on the following:

(i) $90 \%-100 \%$ Excellent

(ii) $70 \%-80 \%$ Satisfactory

(iii) $50 \%-60 \%$ Moderate

(iv) $0 \%-40 \%$ Weak

These categories were obtained based on previous literature in the area (Nurulwahida \& Ahmad Azman, 2014; dan Zaidatun Tasir, 2002). Below are some of the items used in the instrument. All the items were written in the participants' first language to ease understanding.

Sample items used in the Interpersonal Intelligence Instrument

_ $V_{\text {_ }} \quad$ I can learn better by interacting with others.

_ $\sqrt{ }$ _ $\quad$ The more people attended the merrier.

Group activities make me more productive.

__ $\quad$ __ I like communicative activities such as group discussion.

_ ${ } \_$_ $\quad$ To get involve actively in group activities is important to me.

_ $V_{\text {_ }} \quad$ Interviewing is interesting

I am a person who likes working in group

I don't like working alone

To say something nice about other people (friends, teachers, parents) is something meaningful to me

I am concerned about social issues and causes.

$5 \quad$ Number of ticks " $\sqrt{ }$ "

The number of ticks in the items above is 5 , so the scores obtained by the participant is $5 \times 10=50 \%$ which means that the level is moderate.

\section{The Enrichment Activities}

Wagmeister and Shifrin (2000) agree that the application of interpersonal and intrapersonal intelligences in learning activities can attract students to comprehend the content and to interact with others. According to Johnson (2007), interpersonal and intrapersonal intelligence can help teachers to plan learning activities that can elicit students' ability to interact, communicate, and get along with others as well as to understand the needs and ambitions of their own. Some examples of problem-solving activities developed in the treatment of the activities are creating songs, flag and logo of the group. Another example is the completion of the crossword puzzle and treasure hunt in groups.

In the example of conducted intrapersonal activities the students were given the objects of various shapes such as round, triangular and rectangular. Based on these activities, students had to describe and relate these forms to their lives as individuals. In addition, 
the students were also presented with a scenario of conflict between two friends, and they were asked to think about the best way to reconcile both their friends without disappointing anyone.

\section{Data Collection Procedures}

The data collection involved meetings with the orphanage principals to arrange suitable dates for the pre and post- tests as well as treatments without disturbing the school activities. Two weeks after conducting the pre-test, the participants were given treatments for three days and two nights in another premise outside their orphanages. The rationale was to facilitate the orphans of two organizations coming together and to facilitate the implementation of the activities. A week after the treatment, the researchers visited the participants once again at their respective orphanages to administer the post-test. Instructions were given prior to sitting for the pre and posttests. All the data sets were collected and analysed. All in all, the process of data collection took approximately two months. The rationale for the treatment conducted outside the hostel for orphans was to overcome the issue of bias and discrimination between orphans who are not in treatment. Orphans involved in the treatment were in lower secondary (aged 13 to 14 years). Primary school students (aged between 7 to 12 years) were not selected as the activity was not designed for younger students.

\section{Data Analysis}

The collected data were analysed using Statistical Package for the Social Sciences (SPSS). T-test analysis was applied to see the differences in scores between pre and post-test. T-test is used for a parametric test if the data form a normal distribution. Paired Samples T-test was applied in this study and each individual in the sample are measured two times in pre and post-test. Both data were used to make comparative measurements (Field, 2009). For the interview, all the data were recorded, transcribed verbatim and translated for the analysis. The interview data was analysed using thematic analysis.

\section{FINDINGS}

Table 2 shows the demographic profile of the respondents. The respondents consist of 10 males and 36 females. A total of $19(41.3 \%)$ orphans are from MTO and 27 $(58.75 \%)$ of them are from YSO.

Table 2: Demographic profile of the respondents

\begin{tabular}{llc}
\hline Gender & $f$ & Percent $(\%)$ \\
\hline Male & 10 & 21.7 \\
\hline Female & 36 & 78.3 \\
\hline Total & 46 & 100 \\
\hline Orphans Welfare Society & & 41.3 \\
\hline MTO & 19 & 58.7 \\
\hline YTO & 27 & 100 \\
\hline Total & 46 & \\
\hline
\end{tabular}

Table 3 shows the interpersonal profiles of the participants before and after the treatment. The findings of the pre-test of the interpersonal intelligence profile indicated 
that only $4.3 \%(n=2)$ were at an excellent level while $54.3 \%(n=25)$ were at moderate level and $26.1 \%(n=12)$ were at a weak level. Only $15.2 \%(n=7)$ achieved satisfactory level. All in all, the majority ranged between moderate and weak levels. In contrast, the post-test showed vast improvement whereby no student obtained a weak level and most of them achieved an excellent level $69.6 \%(n=32)$. The remaining $28.3 \%(n=13)$ were at a satisfactory level and only $2.2 \%(\mathrm{n}=1)$ were at a moderate level.

Table 3: Interpersonal intelligence based on pre-test and post-tests

\begin{tabular}{lll}
\hline Level & Pre-test Score & Post-test Score \\
\hline excellent & $2(4.3 \%)$ & $32(69.6 \%)$ \\
satisfactory & $7(15.2 \%)$ & $13(28.3 \%)$ \\
moderate & $25(54.3 \%)$ & $1(2.2 \%)$ \\
weak & $12(26.1 \%)$ & $0(0 \%)$ \\
Total & $46(100 \%)$ & $46(100 \%)$ \\
\hline
\end{tabular}

Table 4 indicates the Intrapersonal Profile of the participants before and after the treatment. The findings revealed that the Intrapersonal intelligence profile in the pre-test the participants were at a moderate level with $54.3 \%(\mathrm{n}=25)$ and a satisfactory level with $32.6 \%(n=15)$. The remaining $6.5 \%(n=3)$ were at a weak level. Only $6.5 \%(n=3)$ achieved excellent level. However after treatment, the participants showed a tremendous increase in their intrapersonal intelligence. 52.2\% $(n=24)$ of them achieved excellent level and $45.6 \%(n=21)$ were at a satisfactory level. Interestingly, no student was found at the weak level.

Table 4: Intrapersonal intelligence profile based on pre-test and post-test

\begin{tabular}{lll}
\hline level & Pre-test Score & Post-test Score \\
\hline excellent & $3(6.5 \%)$ & $24(52.2 \%)$ \\
\hline satisfactory & $15(32.6 \%)$ & $21(45.6 \%)$ \\
\hline moderate & $25(54.3 \%)$ & $1(2.2 \%)$ \\
\hline weak & $3(6.5 \%)$ & $0(0 \%)$ \\
\hline Total & $46(100 \%)$ & $46(100 \%)$ \\
\hline
\end{tabular}

The independent t-test was conducted for differences in the interpersonal intelligence. Table 5 shows that there was a significant difference in the interpersonal intelligence before and after the treatment $(\mathrm{t}=-16.730$, $\mathrm{df}=45, \mathrm{p}<.05)$. The null hypothesis was rejected that the mean score of the post test was higher when orphans underwent problem-solving activities based on interpersonal intelligence. The Paired Samples Statistics above shows that the treatment provided improved interpersonal intelligence scores of the participants.

Table 5: Independent T-test Results for Differences in the Interpersonal Intelligence

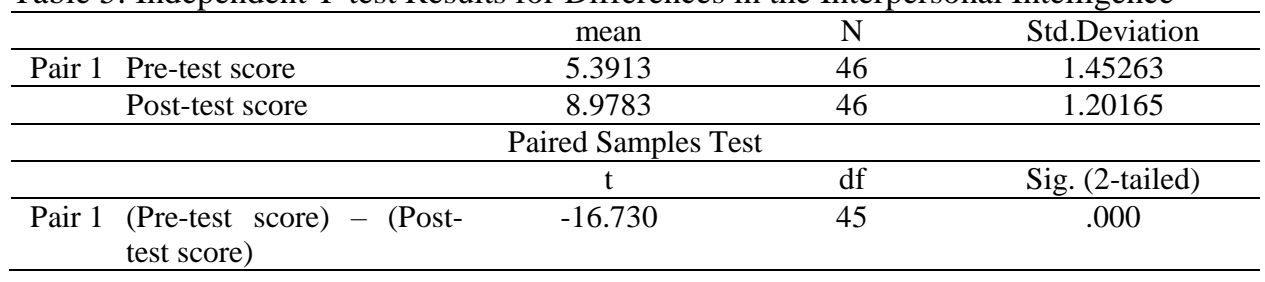


Table 6 shows that there was a significant difference in the intrapersonal intelligence before and after the treatment was given $(t=-13.160, \mathrm{df}=45, \mathrm{p}<.05)$. The null hypothesis was rejected. The mean score was higher after the treatment. The Paired Samples Statistics above shows that the treatment effect enhanced the intrapersonal intelligence of the participants.

Table 6: Independent T-test Results for Differences in the Intrapersonal Intelligence

\begin{tabular}{ccccc}
\hline & mean & $\mathrm{N}$ & Std.Deviation \\
\hline Pair 2 & Pre-test score & 6.3913 & 46 & 1.20145 \\
\hline & Post-test score & 8.4348 & 46 & 1.04673 \\
\hline & Paired Samples Test & & \\
\hline & $\mathrm{t}$ & $\mathrm{df}$ & Sig. (2-tailed) \\
\hline Pair 2 & (Pre-test score) - (Post-test score) & -13.160 & 45 & .000 \\
\hline
\end{tabular}

\section{Interview Findings}

In addition to the qualitative analysis, ten $(n=10)$ orphans were randomly selected to be interviewed to obtain feedback on the conducted intrapersonal and interpersonal activities. The semi-structured interview was carried out after the treatment activities were administered to examine the orphans' perceptions of the interpersonal and intrapersonal enrichment activities. The interview was conducted in a quiet room for about 15-20 minutes. Bryman (2001) indicates that it is important for the researchers to consider the setting which is quiet and private, as well as free from distractions. The interview was conducted in Bahasa Malaysia which is the participants' mother tongue based on their preferences and was translated back by one of the colleagues at the department. Participants were asked to talk about their feelings about the interpersonal and intrapersonal activities and to comment on how they helped to improve their interpersonal and intrapersonal skills.

All the interviews were recorded and transcribed for analysis. The interview data was analysed using thematic analysis whereby the general themes were coded and later reduced to a small manageable set of themes (Creswell, 2007). However, in this paper, only the relevant data to support the quantitative data derived from the pre-test and the post- tests are presented.

\section{Treatment Activities Increase Co-operation}

The interview data revealed that all the students agreed that the activities carried out had successfully enhanced cooperation among the group members and promoted self reflection. Below are some interview responses from the participants:

"Yes, I helped my team members while making a flag and a logo. We worked together "(P4)

"These activities encouraged us to work by contributing ideas and discussing to come up with the best ideas." (P7)

"Yes, we worked together to find alternative and produce creative ideas to solve a given problem." (P10)

These participants helped each other during the activities and they learned to discuss, to contribute ideas, to find alternatives and to be creative in solving the problem assigned 
to them. These kinds of activities eventually helped them to overcome their shyness and lack of confidence when communicating with others.

\section{Treatment Activities improve motivation}

The participants also stated that intrapersonal activities helped them to understand themselves better. Through intrapersonal activities, they could identify their strengths and weaknesses. Furthermore intrapersonal activities gave them motivation to improve their own ability. They mentioned that they could understand themselves better and they became more confident. Here are some of the responses given by the participants:

"Through intrapersonal activities, I became more familiar with myself. This had a positive impact on me because I am more confident with myself. "(P6)

"The benefits I got from this activity are that I realized that the importance of intrapersonal intelligence is one way to know myself." (P8)

\section{Treatment activities Create Self Reflection}

They also explained that they knew their strengths and weaknesses as they learned to reflect on their abilities.

"Intrapersonal activity allows me to know myself better and to know the weaknesses and strengths." (P7)

"Intrapersonal activities allowed me to reflect on myself. I began to realize the strengths and weaknesses of myself." (P4)

"Intrapersonal activity excites me to know myself deeply and improve myself to the maximum level." (P10)

These participants reported that through these treatment activities, they started to think deeply on their strengths or their full potential as well as their weaknesses. They reported that they became more confident and more positive about things in their lives. P8 also mentioned that she now realized the importance of knowing herself while P10 claimed that she became excited that she understood herself well and that she wanted to improve herself to become a much better person. The new discovery about themselves and the motivation to improve themselves were evident in this study.

\section{DISCUSSION}

The study was set out to examine the interpersonal and intrapersonal intelligence profiles of the orphans from two orphanages in the northern part of Malaysia. It was also intended to examine the effects of the treatment activities on the orphans' interpersonal and intrapersonal intelligences and their perceptions of them. The findings indicated that there were significant differences in the interpersonal and intrapersonal intelligences of the orphans before and after the treatment was given. The findings of a pre-test interpersonal intelligence profile revealed that the majority of the orphan's under-study was at the moderate and weak levels. However, vast improvement was seen after the treatment was given whereby no participant obtained a weak level and most of them achieved an excellent level.

The findings of the intrapersonal intelligence, on the other hand, revealed that the participants were at a moderate level during the pre-test. However after the treatment, 
the participants showed a tremendous increase in their intrapersonal intelligence whereby most of them achieved excellent level with no student found at the weak level. Overall, the interpersonal and intrapersonal intelligence activities conducted during intervention improved the participants' intrapersonal and interpersonal intelligence profiles on the post test scores. Teaching approaches based on multiple intelligences allow students to gain more knowledge than traditional teaching. The use of multiple intelligence approach to drug education in Nigeria is found to be more effective than the traditional teaching approaches (Nwagu \& Nwagu, 2013). This is consistent with our findings showing that the treatment activities on interpersonal and intrapersonal intelligence provided to orphans in Malaysia succeeded in raising their profiles of interpersonal and intrapersonal intelligences through interpersonal and intrapersonal intelligence activities and teachers can plan learning activities that encourage students to interact, communicate, and socialize with each other. Apart from that, these activities can also enhance their understanding of their own needs and aspirations. The theory of multiple intelligences that contains the components of interpersonal and intrapersonal intelligences provides changes in the curriculum, assessment and pedagogy (Kornhaber, Ferros, \& Veenema, 2004). Even through this study proves that activity based on intrapersonal and intrapersonal intelligence had brought about changes in the orphans, there are still more that needs to be done. This research is far from finished. A continuous intervention programme needs to be developed to further measure the orphans' improvements. Problem based activity enables orphans to find and generate ideas and alternatives to solve a given problem. Many orphans expressed happiness and excitement after the treatment activities.

Planned activities through interpersonal intelligence enabled them to learn to understand the feelings, motivations, habits and desires of themselves and others. They were also found to encourage their friends to participate actively in the discussions and group activities. Intrapersonal activities such as journal reflections stimulate them to be reflective of themselves. They were able to understand themselves in terms of their strengths, weaknesses, desires and ambitions. Teachers and carers need to be trained to use these interpersonal and intrapersonal activities to enrich orphans' potentials.

The study contributed to the construction of interpersonal and intrapersonal treatment activities that suit Malaysian orphans based on their background and unique cultures. Interpretations related to interpersonal activities are as follows: (a) ability to relate to others in term of Malaysian culture, (b) Interpretation of behaviour and communication based on customs of Malaysia, (c) understands the relationship between people and their situations, including other people based on Malaysian context and religion. Further description of activity related to intrapersonal are as follows: (a) one who is self-aware and involved in the process of changing personal thought, beliefs and behaviour in relation to Malaysia situation and context (b) personal cognizance, (c) personal objectivity, (d) the capability to understand oneself.

\section{CONCLUSION}

In conclusion, enrichment activities that provided interpersonal and intrapersonal skills as evidenced in this study should be carried out regularly at orphanages. Our study has 
proven that orphans' rights to learn cannot be denied and 'no child left behind 'policy needs to be carried through by everybody involved with orphans' well-being. Teachers and carers need to be trained to use these enrichment activities at their orphanages to help maximize the orphans' potentials. These activities not only provided them with problem solving skills, but also fostered cooperation and tolerance among orphans. Learning activities that take into account the multiple intelligences not only affect the performance of these orphans, but they may also influence their attitudes and behaviours in the long run.

Even though this small scale research cannot be generalized to all the orphans in other countries, we feel that the treatment activities could be applied to any orphans in any contexts. We also believe that with proper treatment, orphans or vulnerable children can be pushed to their full potential. Our study only focused on two intelligences, thus it is recommended that other researchers could focus on all the intelligences to gain a complete view of the issue. Our study is also limited in a sense that it investigated only two orphanages in the northern part of Malaysia, with limited samples, therefore the results could not be generalized to all the orphans in this country. Besides, the unequal distribution between male and female participants has to be taken into consideration whereby future research should consider equal number of male and female participants to obtain more convincing findings. This study has realized and addressed the needs of orphans who are often been neglected. As such more studies from other parts of the world are needed to understand this phenomenon.

\section{REFERENCES}

American Psychological Association (1992). Learner-centered psychological principles. Washington, D.C.: American Psychological Association.

Amirah Amaly Syafaat. (2009, Mac 29). Murung akibat krisis ekonomi. Utusan Malaysia.

Armstrong, T. (2000). Multiple intelligences in the classroom. Virginia, USA: Association of Supervision and Curriculum Development.

Armstrong, T. (2003). Multiple intelligences of reading and writing: Making the words come alive. Alexandria, VA: Association for Supervision and Curriculum Development.

Campbell, D. T. \& Stanley, J. C. (1999). Experimental and quasi-experimental design for research. Chicago: Rand McNally \& Company.

Campbell, L., Campbell, B., \& Dickinson, D. (2004). Teaching \& learning through multiple intelligences ( $3^{\text {rd }}$ ed.) United States of America: Allyn and Bacon.

Chan, W. D. (2005). Perceived multiple intelligences and learning preferences among Chinese gifted students in Hong Kong. Journal for the Education of the Gifted, 29, 187-212.

Chua Yan Piaw. (2009). Asas statistik penyelidikan. Kuala Lumpur: McGraw-Hill.

Creswell, J.W. (2012). Educational research: Planning, conducting, and evaluating quantitative and qualitative ( $4^{\text {th }}$ ed.). United States of America: Pearson Education. 
Dummett, C. W. (2006). Successful pedagogies for an Australian multicultural classroom. International Education Journal, 7(5), 778-789.

Field, A. (2009). Discovering statistics using SPSS (3 ${ }^{\text {rd }}$ ed.). London: SAGE Publications Ltd.

Furnham, A., (2009). The validity of a new, self-report measure of multiple intelligence. Current Psychology, 28, 225-239

Gardner, H. (1983). Framed of mind: The theory of multiple intelligence. New York: Basic Books.

Gardner, H. (2004). Audiences for the theory of multiple intelligences. Teachers College Record, 106(1), 212-220.

Grady, D. (2009). Study suggests orphanages are not so bad. Retrieved May 5, 2014, from www.nytimes.com/

Ikhsan Othman \& Rohizani Yaakub. (2010). Aplikasi teori kecerdasan pelbagai dalam pelaksanaan kurikulum. Asia Pacific Journal of Educators and Education, 25, 21-32.

Jamaludin Ramli, Azizi Yahaya, Noordin Yahaya dan Siti Zainab Bt Md. Lazin @ Md. Lazim. (2011). Kemurungan dalam kalangan penghuni rumah anak yatim di daerah Kota Bharu, Kelantan. Unpublished paper. Universiti Teknologi Malaysia.

Johnson, M. (2007). An extended literature review: The effect of multiple intelligences on elementary student performance. Unpublished master dissertation. University of Colifornia.

Karim Hajhashemi \& Wong Bee Eng. (2010). A validation study of the Persian version of McKenzie's multiple intelligences inventory to measure profiles of pre-university students. Pertanika Journal Social Sciences \& Humanities, 18(2), 343-355.

Kornhaber, M. L., Ferros, E., \& Veenema, S. (2004). Multiple intelligence: Best ideas from theory and practice. Needham Heights, MA: Allyn \& Bacon.

Long, C. (2014). Orphans, abuse and the world's most vulnerable children: Recent research (Journalist's Resource). Retrieved March 10, 2014 from http://journalistsresource.org/studies/international/development/orphans-abuse-and-theworlds-most-vulnerable-children-recent-research?

Makame, V., Ani, C. \& Grantham-McGregor, S,. (2002). Acta Peadiatrica, 91(4), 459465.

McKenzie, W. (2000). Multiple intelligences survey. Retrieved March 27, 2013, from http: surfaquarium.com/MI/inventory.htm.

McKenzie, W. (2009). Multiple intelligences and instructional technology $\left(2^{\text {nd }}\right.$ ed.). New Delhi: Viva books Private Limited.

Melissa, M. (2008). Applying what we know. Journal of Women's Health, 17 (9), 14631470.

Ministry of Education. (2001). Education development 2001-2010: Planning in higher education. Kuala Lumpur: Ministry of Education 
Nixon, C. (2013). Orphan- childhood studies. Retrieved April 21, 2014 from www.oxfordbibliographies.com/

Nurulwahida \& Ahmad Azman. (2014). The effectiveness of the modular enrichment activities based on Gardner multiple intelligences and Sternberg thinking skills. Journal of Education and Practice, 5 (2), 55.-62.

Nwagu, E. \& Nwagu, E. (2013). Effectiveness of multiple intelligences teaching approach in drug education of pupils in Enugu State of Nigeria. Journal of Education and Practice, 4 (16), 46-55.

Pappas, S. (2012). Early neglect alters kids' brains. www.livescience.com/21778-earlyneglect-alters-kids-brains.html

Sengendo, J., \& Nambi, J. (2011). The psychological effect of orphanhood: A study of orphans in Rakai Strict. Retrieved April 29, 2014 from www.digitalcollections,anu,edu.au

UNICEF. (2009) Promoting quality education for orphans and vulnerable children: A sourcebook of program experiences in Eastern and Southern Africa. Retrieved May 20, 2014 from www.unicef.org/.../index_53754.html.

Van Ijzendoorn, Marinus H., Luijk, Maartje P. C. M., \& Juffer, F. (2008). IQ of children growing up in children's homes: A meta-analysis on IQ delays in orphanages. Merrill-Palmer Quarterly, 54 (3).

Wagmeister, J., \& Shifrin, B. (2000). Thinking differently, learning differently. Educational Leadership, 58(3), 45-48.

Wan Abdul Kader Wan Ahmad. (2000). Kaunseling kelompok berstruktur. Kuala Lumpur: Dewan Bahasa dan Pustaka.

Wicks-Nelson, R., \& Israel, A. C. (2003). Behavior disorders of childhood (5 $5^{\text {th }}$ ed.). Englewood Cliffs, NJ: Prentice-Hall.

Zaidatun Tasir (2002). Reka bentuk perisian multimedia berasaskan kecerdasan pelbagai pelajar. Tesis Doktor Falsafah. Tidak diterbitkan. Universiti Teknologi Malaysia.

Zimbardo. (2001). Influencing attitudes and changing behavior $\left(4^{\text {th }}\right.$ ed.). Reading, MA: Addison Wesley.

Turkish Abstract

Yetimlerin Potansiyellerini İçsel ve Sosyal Zeka Geliştirme Etkinlikleriyle Ortaya Çıkarma

Yetimler azınlık bir grup olarak düşünülürler ve oldukça önem verilmelidirler böylece kendilerini yalnız bırakılmış hissetmez ve aşağılık duygusu hissetmeden yaşayabilirler. Bu onların şımartılması anlamına gelmez aksine yaşamlarında başarılı olmak için motivasyonu ve güveni onlara aşılar. Aşağılık duygusu yetimlerde içsel ve sosyal zekayla bağdaştırılabilir. Bu çalışma içsel ve sosyal zeka temelli problem çözme aktivitesinin etkisini incelemeyi amaçlamaktadır. Deney grubuna iki yetimhaneden 46 öğrenci katılmıştır. Kullanılan desen tek gruplu ön-test sontestli deneysel çalışmanın nitel ve nicel yaklaşımların bir karışımıdır. Bu çalışmadaki geliştirme etkinlikleri yetimhanelerde düzenli olarak uygulanmalıdır. Çalışmamız yetimlerin öğrenme haklarının göz ardı edilmemesini ve yetimlerin iyiliği için çalışan herkesin "hiçbir çocuk geri 
kalmasın" politikasını uygulaması gerektiğini göstermiştir. Öğretmanler ve ilgili kişiler yetimlerin potansiyelini maksimize etmek için bu aktiviteleri uygulayabilmek için eğitim almaya ihtiyaç duymaktadırlar.

Anahtar Kelimeler: yetimler, içsel zeka, sosyal zeka, deneysel ve karma metod, geliştirme etkinlikleri

\section{French Abstract}

L'Enrichissement des Potentiels d'Orphelins par Activités d'Enrichissement d'Intelligence Interpersonnelles et Intrapersonal

On considère des orphelins une minorité et on devrait leur donner le plus grand accent pour qu'ils ne se sentent pas tés à l'écart et peuvent construire leurs propres vies sans un sentiment de l'humilité. Ceci ne signifie pas que les orphelins devraient être choyés au lieu de cela on devrait leur donner la confiance et la motivation pour lutter pour le succès plus tard dans la vie. L'humilité parmi des orphelins peut être associée aux intelligences interpersonnelles et intrapersonal. Cette étude a pour but d'évaluer l'impact de traitement d'activité de résolution de problèmes basé sur les intelligences interpersonnelles et intrapersonal. 46 étudiants de deux orphelinats ont été impliqués comme le groupe de traitement. Le design de recherche utilisé était un design de pretest-posttest à un groupe appliqué par une combinaison d'approches quantitatives et qualitatives. Les activités d'enrichissement qui ont fourni des compétences interpersonnelles et intrapersonal comme en témoigne cette étude devraient être effectuées régulièrement aux orphelinats. Notre étude a prouvé les droits de ces orphelins d'apprendre ne peut pas être négligé et ' aucun enfant laissé ' la politique(police) doit être exécuté par tout le monde impliqué avec le bien-être des orphelins. Les professeurs et des travailleurs sociaux doivent être formés pour utiliser ces activités d'enrichissement à leurs orphelinats pour aider maximiser les potentiels des orphelins.

Mots Clés: Orphelins, Intelligence Interpersonnelle, Intrapersonal Intelligence, Recherche de Méthode Expérimentale et Mixte(mélangée), Activités d'Enrichissement

\section{Arabic Abstract}

إمكانيات إثراء الأيتام من خلال العلاقات الثخصية وأنثطة تقوية الذكاء داخل الثخص

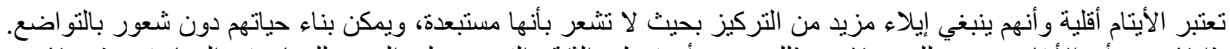

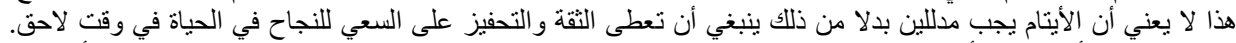

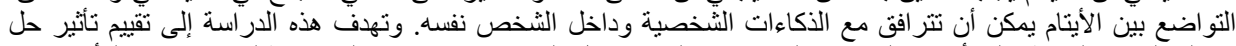

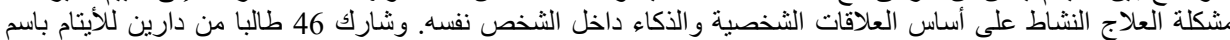

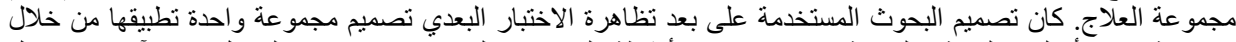

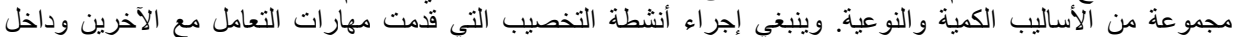

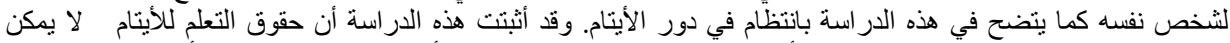

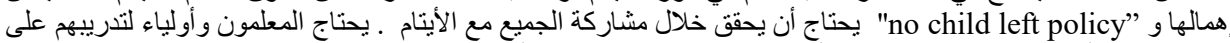
استخدام هذه الأنشطة التخصيب في دور الأيتام لمساعدة تعظيم إمكانات الأيتام.

الكلمات الرئيسية: الأيتام، والذكاء بين الأشخاص والذكاء داخل الشخص نفسه والتجريبية والبحثية أسلوب المختلط، أنشطة 